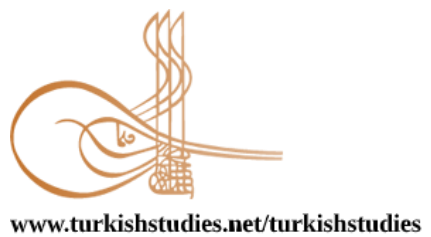

Turkish Studies

www.turkishstudies.net/turkishstudies

eISSN: $1308-2140$

BALKAN
UNIVERSTY

Sponsored by IBU

Research Article / Araştırma Makalesi

\title{
Sınıf Öğretmenliği Lisans Öğrencilerinin Pandemi Sürecindeki Çevrim İçi Öğrenme Deneyimlerinin İncelenmesi
}

\author{
The Online Learning Experiences of Primary School Pre-Service Teachers During the Covid-19 \\ Pandemic Process
}

\author{
Engin Karahan* - Mehmet Arif Bozan ${ }^{* *}-$ Ahmet Oğuz Akçay ${ }^{* * *}$
}

\begin{abstract}
Distance education, which to become more widespread in the near future, has become a more commonly used educational term with the pandemic process. When face-to-face education is not possible, distance education has been used as an important method for the sustainability of education. Due to the sharp transition to distance education in the pandemic period, the process of distant education in this period was also an important curiosity. An important question is how quickly faculty members and students can adapt to this system, with a sudden transition from face-to-face to distance education. In this study, the students who are important stakeholders of this process are examined critically. Therefore, the case study design was chosen for the study. The participants of the study were 40 students from the primary school teacher education program at a public university. Typical case sampling method was used for selecting the participants of the study. The data collected for this study involved open-ended questionnaire forms and semi-structured interviews. The participant students were first asked to fill out the questionnaires consisting of open-ended questions. In the second stage, based on the answers in the open-ended questionnaire form, four students who participated the second stage of the data collection voluntarily were interviewed. In the analysis of the data, both content analysis and descriptive analysis were used respectively. As a result of the analyzes, the themes of teaching process, encountered barriers, learning environments and suggestions emerged. Based on the findings, it was concluded that synchronous lessons were found more efficient. Also, some students stated the difficulties they face during the online learning process, as well as the technological incompetency of the instructors. Based to these results, suggestions were provided for the academic staff and students.
\end{abstract}

\footnotetext{
${ }^{*}$ Dr. Öğretim Üyesi, Eskişehir Osmangazi Üniversitesi, Eğitim Fakültesi, Eğitim Bilimleri Bölümü Assist. Prof., Eskişehir Osmangazi University, Faculty of Education, Department of Education Sciences ORCID 0000-0003-4530-211X

ekarahan@ogu.edu.tr

** Araştırma Görevlisi, İstanbul Aydın Üniversitesi, Eğitim Fakültesi, Temel Eğitim Bölümü Research Assistant, İstanbul Aydın University, Faculty of Education, Department of Basic Education ORCID 0000-0003-3554-4828

mehmetbozan@aydin.edu.tr

**** Dr. Öğretim Üyesi, Eskişehir Osmangazi Üniversitesi, Eğitim Fakültesi, Temel Eğitim Bölümü Assist. Prof., Eskişehir Osmangazi University, Faculty of Education, Department of Basic Education ORCID 0000-0003-2109-976X aoakcay@ogu.edu.tr
}

Cite as/ Atıf: Karahan, E. \& Bozan, M. A. \& Akçay, A. O. (2020). Sınıf öğretmenliği lisans öğrencilerinin pandemi sürecindeki çevrim içi öğrenme deneyimlerinin incelenmesi, Turkish Studies, 15(4), 201-214. https://dx.doi.org/10.7827/TurkishStudies.44348

Received/Geliş: 19 June/Haziran 2020

Accepted/Kabul: 15 August/Ağustos 2020

Copyright $\mathbb{C}$ MDE, Turkey

Checked by plagiarism software

Published/Yayın: 30 August/Ağustos 2020

CC BY-NC 4.0 


\section{Structured Abstract: Introduction}

Distance education, which to become more widespread in the near future, has become an important point with the pandemic process. When face-to-face education is not possible, distance education has been used as an important method for the sustainability of education. Due to the sharp transition to distance education in the pandemic period, the process of distant education in this period was also an important curiosity. This study aims to investigate the distant education processes that occurred during the pandemic era. Therefore, the experiences and evaluations of the students who enrolled the Primary Teacher Education Program at Faculty of Education were focused. Thus, the following research questions guided the study: (1) How do undergraduate students from a primary teacher education program experience distance education during the pandemic era? (2) How do undergraduate students from a primary teacher education program evaluate the distant education practices during the pandemic era?

\section{Methods}

This study was designed in line with qualitative research approaches. Qualitative research is defined as a process based on a holistic analysis of perception, events or situations in their natural environment. In this study, it is aimed to examine the evaluations of the students who attended the classroom teaching program about their online learning experiences in the pandemic process in a holistic way. Accordingly, a case study design was selected to examine a phenomenon in its natural environment with an integrative interpretation and to reveal the interactions between the phenomena and the environment in which it occurs. Since the phenomena investigated in this study was determined as the evaluations of the undergraduate students' experiences in the pandemic process, a holistic single case study was chosen.

The participants of the study were 40 students who enrolled the primary teacher education program at faculty of education. Typical case sampling, which is frequently used in case studies, is used as the sampling method of the study. It is essential to select the situations that are likely to be encountered within the scope of the diversity in the typical case sampling. Considering that the vast majority of undergraduate students continue their education online during the pandemic process, it is considered that the experience of undergraduate students, who are the participants of the study, is typical.

In case studies, it is recommended to use multiple data collection tools to describe the case or situation in a holistic and detailed manner. Accordingly, open-ended questionnaires and semi-structured interviews form the data collection tools of the study. The data collection process of the research was carried out in two phases. In the first phase, 40 students who participated in the study were asked to answer open-ended questions once a week for three weeks. In the second phase, semi-structured interviews were prepared based on the answers received from students to open-ended questionnaires. Semi-structured interviews were conducted with four students selected on a voluntary basis among the participant students via online technologies.

The analysis of the data involved content analysis and descriptive analysis methods respectively. The data obtained from open-ended questionnaires were analyzed by content analysis method and themes were obtained. Then, the codes obtained from the semi-structured interviews were edited and interpreted through the use of the themes obtained for the purpose of the study. Therefore, in the data analysis process of the study, first of all induction and then deductive approach was adopted. In order to ensure the validity of the research, data collection processes are described in detail and direct quotations from the participants are included in the findings. In addition, the data obtained were analyzed by three researchers and the results were compared and the consistency between the coders was checked.

\section{Findings and Discussion}

The statements obtained in line with the answers given to the semi-structured interview questions and open-ended questions in order to transfer the classroom learning undergraduate students' online learning experiences in the pandemic process are firstly stated under themes, then categories and finally codes. The themes that emerged based on the analysis of the data were teaching process, encountered barriers, learning environments and suggestions. As a result of open-ended questionnaires and semi-structured interviews, most students stated that the synchronous courses were more productive by mentioning the disadvantages and advantages of both synchronous and asynchronous courses. The literature also argues the advantages and disadvantages of synchronous and asynchronous courses in the distance education. Another finding obtained in the research is that the students suffer from technological deprivation due to the conditions they experience. 
Also, students believed that the academic staff do not have sufficient digital competence within the scope of distance education. The last prominent finding in the research is the opinions of students about the learning environments in distance education. During the interviews, it was concluded that the students preferred the synchronous lessons in which they could communicate with the lecturer via camera and microphone.

\section{Recommendations}

According to the results of the research, some suggestions are presented for the quality of online education. As the students follow the curriculum constantly and work regularly, it is important in online education as well as in any educational environment. Another important factor is that students participate regularly in synchronous and asynchronous lessons. It is recommended that the instructors develop the content intended to ensure the participation of students while planning their courses. It is recommended that faculty members be open to the use of technology, which will be more involved in education in the near future, and follow technological developments. It is recommended that faculty members plan their online lessons in advance and more actively. Last, in order to increase the quality of online education, it is recommended to give by blending in synchronous and asynchronous lessons.

Keywords: Higher education, Pandemic, Distance Education, Online Learning, Case Study, Primary Education

Öz: Yakın gelecekte daha fazla yaygın hale gelmesi düşünülen uzaktan eğitim, pandemi süreci ile birlikte önemli hale gelmiştir. Yüz yüze eğitimin devam etmesinin olanaksız olduğu bu süreçte eğitimin sürdürülebilirliği açısından da uzaktan eğitim önemli bir metod olarak kullanılmıştır. Uzaktan eğitime keskin bir geçiş olması nedeniyle bu sürecin nasıl gerçekleştirildiği de önemli bir merak konusu olmuştur. Bir başka soru ise, yüz yüze eğitimden uzaktan eğitime ani geçiş olmasıyla birlikte öğrencilerin bu sisteme ne kadar uyum sağlayabilecekleri olduğudur. Bu araştırmada da bu sürecin önemli paydaşı olan lisans öğrencileriyle birlikte derinlemesine irdelemek amaçlanmıştır. Bu nedenle bu araştırma nitel araştırma yöntemlerinden durum çalışması olarak desenlenmiştir. Araştırmanın katılımcıları devlet üniversitesinde sınıf öğretmenliği lisans programında öğretim sürecini devam ettiren 40 lisans 3. sınıf öğrencileridir. Araştırma katılımcıları seçilirken tipik durum yöntemi kullanılmıştır. Veri toplama araçları olarak açık uçlu form ve yarı yapılandırılmış görüşmeler kullanılmıştır. Veri toplama araçları oluşturulurken ilk önce üç araştırmacı birlikte yazılı veri toplama aracı sorularını oluşturmuştur. Daha sonrasında bu formlara gelen cevapların analizlerinden yola çıkalara görüşme formu oluşturulmuştur. Araştırma verileri toplanırken ilk olarak üç hafta boyunca haftada bir öğrencilerden açık uçlu sorulardan oluşan yazılı formu doldurmaları istenmiştir. İkinci aşamada ise açık uçlu formda yer alan yanıtlardan yola çıkarak 40 öğrenci arasından gönüllü dört öğrenci ile görüşme yapılmıştır. Toplanan verilerin analizinde ise sırasıyla içerik analizi ve betimsel analiz kullanılmıştır. Yapılan analizler sonucunda öğretim süreci, karşılaşılan engeller, öğrenme ortamı ve öneriler temalarına ulaşılmıştır. Araştırmada senkron derslerin daha verimli olduğu, bazı öğrencilerin internet, teknoloji gibi yetersizliklere sahip olduğu, yine bazı öğretim elemanlarının teknolojik olarak yeterlirliliğinin iyi olmadığı, görüntülü ve sesli çevrimiçi eğitim ortamlarının daha çok faydalı olabileceği sonuçlarına ulaşılmıştır. Bu sonuçlara göre araştırmada öğretim elemanlarına ve öğrencilere öneriler sunulmuştur.

Anahtar Kelimeler: Pandemi, Yükseköğretim, Uzaktan Eğitim, Çevrim İçi Öğrenme, Durum Çalışması, Sınıf Öğretmenliği

\section{Giriş}

2019 yılının Aralık ayında Çin'in Wuhan kentinde çıkan Covid-19 virüsü 2020 yılında dünya geneline yayılarak pandemiye sebep olmuştur. Virüsün insanlar arasında hızlı ve kolayca yayılabilmesi, hükümetleri, bazı önlemler almaya zorlamıştır. Ülkelerin sınırlarını kapatmaları, ülke içi seyahatlere kısıtlamaların getirilmesi, insanların bir arada oldukları sosyal faaliyetlerin yasaklanması, eğitim-öğretim sürecinin uzaktan eğitim modeline dönüşmesi, çalışan kişilerin evden çalışmaları bu önlemlerden bazılarıdır (Birleşmiş Milletler Kalkınma Programı [UNDP] Türkiye, 2020). Bu önlemlerin sonucu olarak çoğu alan bu durumdan etkilenmiş ve bu yeni soruna çözüm yolları geliştirmiştir. Etkilenen bu alanların birisi de eğitimdir. 
Virüsün bulaşabilirlik kapasitesinin yüksek olması yüz yüze eğitimi olanaksız hale getirmiştir. Ülkeler eğitim-öğretimin devam etmesi amacıyla uzaktan çevrim içi eğitime geçmişlerdir. Virüsün ilk başladığı yer olan Çin'de okul öncesinden, lisans düzeyine kadar tüm seviyelerde uzaktan eğitime geçilmiş ve öğrencilerin kolay ulaşmalarını sağlamak amacıyla online eğitim sistemlerini daha kolay erişilebilir hale getirmiştir (Lau ve diğerleri, 2020). Virüsten en çok etkilenen ülkelerin başında gelen Amerika Birleşik Devletleri'nde ise eğitim süreci üniversiteler ve eyaletlere göre farklılık göstermiştir. Türkiye'de Milli Eğitim Bakanlığı 2012'de sunulan Eğitim Bilişim Ağını (EBA) daha aktif hale getirerek ve Türkiye Radyo Televizyon Kurumu (TRT) ile işbirliği yaparak derslerin uzaktan eğitime dönüşümü için önemli adımlar atmıştır. Üniversiteler düzeyinde ise Yüksek Öğretim Kurumu (YÖK) yaptığı birtakım çalışmalar sonucunda 123 üniversitenin uzaktan eğitim sistemlerinin eğitim-öğretim dönemini tamamlamak için yeterli olduğunu, bu alanda yetersiz olan üniversitelerinde diğer üniversitelerle işbirliği içerisinde, TRT desteğiyle ve İstanbul Üniversitesi, Anadolu Üniversitesi ve Atatürk Üniversitesinin açıköğretim sistemiyle destekleneceğini bildirmiştir (YÖK, 2020). YÖK uzaktan eğitim çalışmalarını mevzuat, altyapı, insan kaynakları, içerik ve uygulama olarak 5 temel yapıda ele almıştır. Sadece bir dönemle sınırlı olacak şekilde altyapıları yeterli olan üniversitelerin uzaktan eğitim yapmaları için uygun mevzuat geliştirilmiş, üniversitelerle yapılan görüşmeler sonucunda altyapı bilgisi alınıp yeterli olmayan üniversiteler için çözüm önerileri sunulmuştur (YÖK, 2020). Buna ilave olarak uygulama kısmında da üniversitelerin akademik takvimlerine uygun olarak sürecin devam ettirilmesi ve süreç sonunda da ölçme değerlendirme işlemlerinin yapılması gerektiği belirtilmiştir.

Gelişen teknoloji ile birlikte eğitim-öğretimin uzaktan eğitime evrileceği görüşleri, bu salgın ile birlikte tekrar ön plana çıkmıştır. Dünyada ilk olarak mektupla başlayan uzaktan eğitim, teknolojinin gelişmesiyle birlikte radyo, televizyon ve internet üzerinden daha yaygın ve kolay ulaşılabilir hale gelmiştir. Ülkemizde de uzaktan eğitim çok eski tarihlerde uygulanmaya başlansa da 1982 yılında Anadolu Üniversitesine açık öğretim yapma hakkının verilmesiyle birlikte yaygınlaşarak önem kazanmıştır (Bozkurt, 2017). Günümüzde de uzaktan eğitim üniversitelerde daha çok lisansüstü eğitimde ve birçok üniversitenin açmış olduğu uzaktan eğitim programları ve dersleriyle birlikte yaygın şekilde kullanılmaktadır (YÖK, 2020). Uzaktan eğitim, sürece dahil olan paydaşların eğitime katıldıkları mekan olarak istedikleri yerden katılabilmeleri ve zaman olarak da farklı bölgelerde yaşayan farklı durumdaki kişileri bir araya getiren esnek bir yapıya sahiptir (Hiltz ve Wellman, 1997). Uzaktan eğitim ihtiyaç anlarında da eğitimin sürdürülebilirliği açısından bu yönüyle öneme sahiptir. Uzaktan eğitimin, eğitimde fırsat eşitliği oluşturması, farklı öğrenme ortamlarına sahip olması ve sunması, öğrencilere bireysel çalışma ortamı sunması, ölçme araçlarındaki esneklik, teknolojinin imkanlarından daha fazla faydalanma imkanı sunması, öğretim üyeleri ile kolay iletişim bakımından olumlu yönlere sahip olduğu belirtilmiş̧ir (Doğan, 2014; Zhang ve Nunamaker, 2003; Kaya ve Önder, 2002). Uzaktan eğitimin avantajlı yönleri literatürde şu maddelerle belirtilmiştir:

- Uzaktan eğitim, öğrencilere eğitime erişim konusunda mekan ve zaman olarak büyük bir esneklik sağlamaktadır.

- Diğer öğrencilerle konuşma endişesi yaşayan ve çekingen olan öğrencilerin uzaktan eğitim sistemi üzerinden daha rahat bir şekilde iletişim kurmalarına yardımcı olabilir.

- Uzaktan eğitimde öğrenciler mekan olarak istediği yerden erişim sağlayabildikleri için maliyet olarak uygundur.

- Uzaktan eğitim yüz yüze eğitime göre bireysel farklılıkları dikkate almak için daha fazla imkana sahiptir.

- Uzaktan eğitim gelişen teknoloji ile birlikte laboratuvar gibi fiziksel eksikliklerin sanal ortamda giderilmesiyle daha anlamlı dersler için olanak sağlamaktadır. 
- Uzaktan eğitim bireylerin kendi öğrenme hızlarına göre ilerlemeleri için firsat sunmaktadır. $\mathrm{Bu}$ yüzden öğrencilerin yaşadıkları kaygıların azalabileceği söylenebilir (Codone, 2001; Urdan ve Weggen, 2000; Amer, 2007; Klein ve Ware, 2003; Algahtani, 2011; Marc, 2002; Akt. Arkorful ve Abaidoo).

$\mathrm{Bu}$ olumlu yönlerin yanı sıra uzaktan eğitimin, teorik derslere çözüm olduğu fakat uygulamalı dersler konusunda eksik kaldı ̆̆ı, kişilerin sosyal öğrenme alanlarından uzak kalması soru işaretleri oluşturmuştur. Bir başka soru ise, yüz yüze eğitimden uzaktan eğitime ani geçiş olmasıyla birlikte öğretim üyelerinin ve öğrencilerin bu sisteme ne kadar uyum sağlayabilecekleri olduğudur. Ertmer (1999), derslere teknoloji entegrasyonunda iki tür bariyer olduğunu bildirmiştir. Birinci tür (dışsal) bariyerler teknolojik araçlara, yazılımlara, programlara erişim eksikliği, öğretimin planlanmasında yeterli zaman ya da teknik destek eksikliği olarak tanımlanırken, ikinci tür (içsel) bariyerlerde ise öğretim elemanlarının teknoloji hakkındaki olumsuz tutumları, değişime karşı olumsuz tutum ve teknolojik pedagojik alan bilgisi eksikliği olarak tanımlanmıştır (Ertmer, 1999). Teknolojinin kullanıldığı eğitim ortamının etkili olabilmesi için öğretim elemanlarının, alan bilgisine, pedagojik bilgiye ve teknoloji bilgisine sahip olması gerekmektedir (Koehler ve Misra, 2008). Ani bir geçiş ve zorunlulukla başlayan uzaktan eğitim sürecinde bu bariyerlerin aşılıp aşılmadığı ve öğretim elemanlarının bu sürece ne kadar hazır olduğu da diğer bir endişe duyulan konudur.

Sonuç olarak bu araştırmada, Covid-19 pandemisiyle gelen uzaktan eğitim sürecini derinlemesine incelemek amaçlanmıştır. Bu amaçla bu süreçte yer alan sınıf öğretmenliği lisans öğrencileri ile gerçekleştirilen uzaktan eğitim uygulamalarını derinlemesine betimlemek amaçlanmıştır. Bu kapsamda aşağıda yer alan araştırma sorusuna cevap aranmıştır.

- Sınıf öğretmenliği lisans öğrencilerinin pandemi sürecindeki çevrim içi öğrenme deneyimleri doğrultusunda değerlendirmeleri nasıldır?

\section{Yöntem}

Bu çalışma nitel araştırma yaklaşımları doğrultusunda tasarlanmıştır. Nitel araştırmalar algı, olay ya da durumların doğal ortamında bütüncül bir biçimde incelenmesine dayanan bir süreç olarak tanımlanmaktadır (Yıldırım ve Şimşek, 2013). Bu çalışmada ise sınıf öğretmenliği programında eğitim gören öğrencilerin pandemi sürecindeki çevrim içi öğrenme deneyimlerine dönük değerlendirmeleri kendi bağlamı içerisinde bütüncül bir biçimde incelenmesi amaçlanmıştır. Bu doğrultuda, bir durumun bütünleyici bir yorumla doğal ortamında derinlemesine incelenmesini ve durum ile ortam arasındaki etkileşimleri ortaya konulmasını amaçlayan durum çalışması deseni tercih edilmiştir (Yıldırım ve Şimşek, 2013). Durum çalışmalarında sınırları belirlenmiş bir olgunun bu sınırlar içerisinde tüm detayları ile betimlenmesi esastır (McMillan, 2004). Bu çalışmada araştırılan durum sınıf öğretmenliği lisans öğrencilerinin pandemi sürecindeki deneyimlerine dönük değerlendirmeleri olarak belirlenmiş olduğundan, bütüncül tek durum deseni tercih edilmiştir.

\section{Katılımcilar}

Çalışmanın katılımcılarını bir üniversitenin sınıf öğretmenliği lisans programı 3. sınıfında öğrenim gören 40 öğrenci oluşturmaktadır. Çalışmanın örnekleme yöntemi olarak durum çalışmalarında sıklıkla kullanılan tipik durum örneklemesi kullanılmıştır. Tipik durum örneklemesinde var olan çeşitlilik kapsamında karşılaşılma olasılığı yüksek olan durumların seçilmesi esastır. Pandemi sürecinde lisans öğrencilerinin büyük çoğunluğunun eğitimlerine çevrim içi (senkron ve asenkron) olarak uzaktan devam ettikleri göz önünde bulundurulduğunda çalışmanın katılımcılarını oluşturan lisans öğrencilerinin deneyimlerinin tipik niteliği taşıdığı düşünülmektedir. Katılımcıların kimlikleri gizli tutmak amacıyla Ö1, Ö2, Ö3,...... Ö40 şeklinde kodlanmıştır. Bu katılımcılar içerisinde Ö18, Ö19, Ö34 ve Ö35 ile yar1-yapılandırılmış görüşmeler gerçekleştirilmiştir. 


\section{Veri toplama araçları}

Durum çalışmalarında olgu ya da durumun bütüncül ve detaylı bir şekilde betimlenmesi amacıyla çoklu veri toplama araçlarının kullanılması önerilmektedir. Bu doğrultuda çalışmanın veri toplama araçlarını açık uçlu soru formları ve yarı-yapılandırılmış görüşmeler oluşturmaktadır. Açık uçlu soru formları üç araştırmacı tarafından tartışılarak hazırlanmıştır. Araştırmanın veri toplama süreci iki safhada gerçekleştirilmiştir. İlk safhada çalışmaya katılım gösteren 40 öğrenciden üç hafta boyunca haftada bir açık uçlu sorulara yanıt vermeleri istenmiştir. Bu açık uçlu sorular, her hafta değişmekle birlikte temelde katılımcıların pandemi sürecindeki uzaktan öğrenme deneyimlerine ve bu deneyimler sonunda ortaya çıkan sürece yönelik değerlendirmelerine odaklanmıştır. Bu süreçte her hafta öğrencilerin pandemi sürecindeki deneyimlerine dönük farklı bir noktaya odaklanılmıştır. İlk safha tamamlandıktan iki hafta sonra ikinci safhaya geçilmiştir. İkinci safhada ise, öğrencilerden açık uçlu soru formlarına alınan yanıtlardan yola çıkarak hazırlanan yarı-yapılandırılmış görüşmeler uygulanmıştır. Görüşme sorularının içeriği açık uçlu soru formlarıyla benzerlik göstermekle birlikte katılımcıların deneyimlerini ve değerlendirmelerini derinlemesine inceleme firsatı sunmuştur. 40 öğrenci arasından gönüllülük esasına göre seçilen dört öğrenci ile çevrim içi teknolojiler yoluyla uzaktan görüşmeler gerçekleştirilmiştir. Bu görüşmelerde öğrencilerin pandemi sürecindeki çevrim içi öğrenme deneyimlerini değerlendirmelerine yönelik sorular yöneltilmiştir. Bu görüşmeler eğitim sürecinin sonunda gerçekleştirilmiş olup, her bir görüşme yaklaşık 45 dakika sürmüştür.

\section{Veri analizi}

Araştırma kapsamında toplanan verilerin analizinde sırasıyla içerik analizi ve betimsel analiz yöntemi uygulanmıştır. Açık uçlu soru formlarından elde edilen veriler içerik analizi yöntemi ile analiz edilerek temalar elde edilmiş̧tir. Sonrasında, yarı-yapılandırılmış görüşmelerden elde edilen kodlar çalışmanın amacına yönelik elde edilen temaların kullanılması yoluyla düzenlenerek yorumlanmıştır. Dolayısıyla, çalışmanın veri analizi sürecinde önce tümevarım sonrasında ise tümdengelim yaklaşımı benimsenmiştir. Araştırmanın geçerliliğini sağlamak adına veri toplama süreçleri detaylı bir şekilde betimlenmiş ve bulgularda katılımcılardan doğrudan alıntılara yer verilmiştir. Araştırmanın geçerliğini sağlamak amacıyla bir diğer yöntem olarak katılımcı teyidi yapılmıştır. Yarı yapılandırılmış görüşmeler sonrası öğrencilerden teyit alınmıştır. Ayrıca araştırmanın güvenirliği açısından, elde edilen veriler üç araştırmacı tarafından analiz edilerek sonuçlar karşılaştırılmış ve kodlayıcılar arasındaki tutarlılık kontrol edilmiştir. Araştırma güvenirliği için bir başka yöntem olarak veri toplama ve analiz süreçleri ayrıntılı olarak açıklanmıştır.

\section{Bulgular}

Sınıf öğretmenliği lisans öğrencilerinin pandemi sürecindeki çevrim içi öğrenme deneyimlerinin aktarılması amacıyla yarı yapılandırılmış görüşme sorularına ve açık uçlu sorulara verdikleri cevaplar doğrultusunda elde edilen alıntılar önce temalar, sonra kategoriler ve son olarak kodlar altında belirtilmiştir. Katılımcıların görüşme sırasında bazı sorulara verdiği cevaplar birden fazla kodun altına alınmıştır. Şekil 1 çalışma kapsamından oluşturulan temaları göstermektedir. 
Şekil 1. Çevrim İçi Öğrenme Deneyimlerine İlişkin Temalar

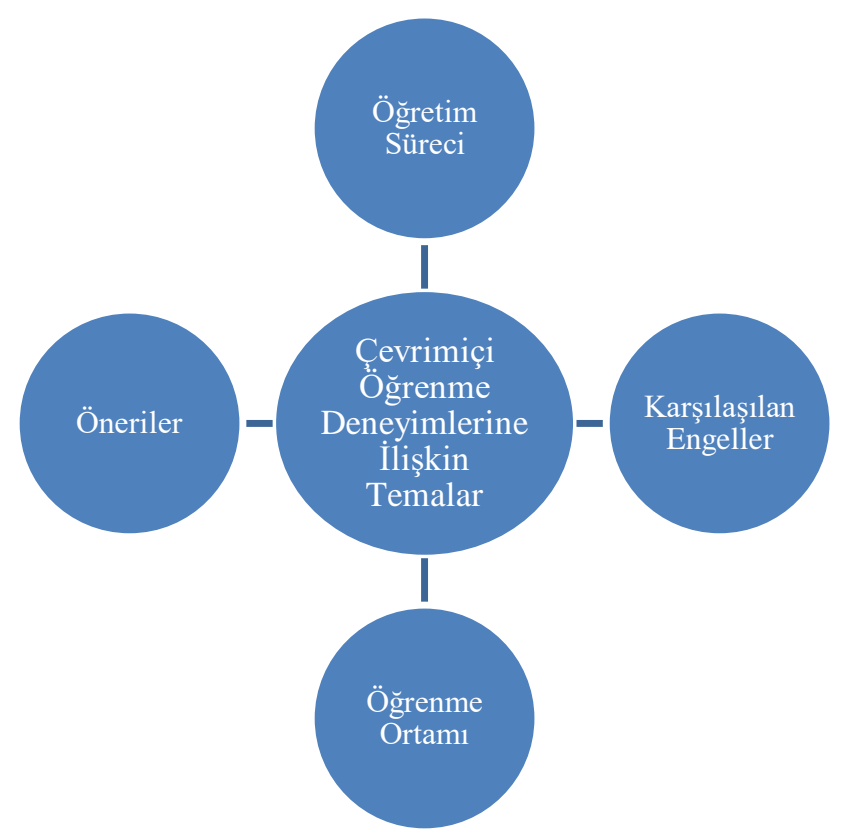

\section{Öğretim Süreci}

Öğrenciler pandemi sürecindeki çevrim içi öğrenme deneyimlerini ortaya koyarken öğretim süreçleri ile ilgili değerlendirmelerde bulunmuşlardır. Bu değerlendirmelerin temelinde ise uzaktan derslerin senkron ya da asenkron yürütülmesinin karşılaştırılması yatmaktadır. Bu karşılaştırmalar esnasında hem senkron hem de asenkron derslerin dezavantajları ve avantajlarından bahsetmişlerdir. Bazı öğrenciler senkron derslerin daha verimli geçtiğini belirtirken diğer bir grup ise asenkron derslerin daha yürütülebilir olduğunu vurgulamışlardır. Örneğin, aşağıdaki örnekte yer alan Ö24 kodlu öğrenci senkron derslerin asenkron derslere göre etkileşimli yapısı sebebiyle öğrenmenin gerçekleşmesi açısından daha avantajlı olduğunu belirtmiştir:

Senkron derslerden bahsedecek olursak, asenkron derslere göre eğiticiliğinin çok daha yüksek olduğu bir gerçek. Senkron derslerde öğretmen ve öğrenci karşıllkll iletişim kurabiliyor, öğrenci anlamadı̆̆ yerleri öğretmenine aninda sorup anında cevap alabiliyor. Bu bakımdan çok daha etkili olsa da, her kesimin ulaşabilmesi pek mümkün değil. \#Ö24

Bununla birlikte senkron derslerin sunduğu avantajlara rağmen, bu tarz işlenen derslerin öğrencilerin sahip olduğu teknolojik imkanlar da göz önünde bulundurulduğunda çeşitli dezavantajları da beraberinde getirdiği belirtilmiştir. Bunların arasında öğrencilerin internet kotalarından kaynaklı sorunlar yaşadıkları görülmüştür:

Çünkü aynı anda birçok kişinin online olması gereken konferans video kaynakl uygulamalar kotamızdan oldukça fazla tüketmektedir. \#Ö2

Öğrencilerin internet bağlantılarına güvenmemeleri sebebiyle yaşadıkları sıkıntılar da senkron yürütülen derslerin dezavantajlarından biri olarak ortaya konulmuştur. Özellikle sınavların senkron gerçekleştirilmesi durumunda öğrencilerin yaşamaları ihtimal dahilinde olan sorunların, onlarda strese sebep olduğu öğrenciler tarafindan paylaşılmıştır.

Senkron olarak gerçekleşen bir diğer çok önemli sorun ise internet üzerinden yapılan vize sınavlarında oluşabilecek elektrik, internet bağlantısı kesintisi, bilgisayar bozulması gibi teknik sorunlardır. Bu gibi sorunlarda sınavımı tamamlayamama ilgili sınavdan 0 alma gibi bir sorunla karşı karşıya kalabilme kaygısı içerisindeyim. Bu gibi durumlarda ilgili 
uzaktan ĕgitimin online sinavlara teknik olarak iyi hazırlanması ve öğrenci açısından oluşabilecek teknik aksaklıklarda nasıl bir yol izlemesi gerekeceğini tespit etmesi gerekmektedir. \#Ö21

Asenkron derslerde senkron derslere göre zaman kısıtlamasının olmaması ve öğrencilerin istediği zaman dersi takip edebilmeleri asenkron derslerin sunduğu avantajlar arasında belirtilmiştir.

\section{Asenkron derslerde bir sıkıntım olmadı belli bir zaman kısıtı olmadı̆̆ı için kolaylıkla işlerimi yapabildim. \#Ö4}

Bununla birlikte asenkron derslerin ödev şeklinde yürütülmesinin bu işleyişin verimini düşüren bir faktör olarak ortaya çıktığını savunmuşlardır. Haftalık ödevler üzerinden giden dersler kapsamında verilen ödevlerin yüzyüze derslere göre çok daha fazla olması sebebiyle, ödev yetiştirmek için harcanan çabanın dersi öğrenmelerinin önünde engel olarak ortaya çıktığını belirtmişlerdir.

\section{Çoğu asenkron derslerimizde konulara doğru düzgün olarak neredeyse hiç çalışma firsatı bulamıyoruz. Konulara çalışmak yerine farklı derslerin ya da o dersin sürekli olarak ödevini yapıyoruz. İnanın ki hem konuyu anlamaya çalışıp hem ödevi anlamaya çalışmak ve ardından ödevi yapmak çok uzun sürüyor. \#Ö19 \\ Benim için asenkron dersinin en olumsuz yanı ödevler. Hocalarımızın bir kısmı senkron ders yapmadıkları için konuyu anlamamız adına ödeve ă̆ırlık vermiş durumdalar. \#Ö37}

Katılımcıların öğretim sürecinin yürütülmesi ile ilgili en güçlü eleştirileri sürecin ödevler üzerinden yürütülmesine dönük olmuştur. Birçok öğrenci sürecin ders yönetim sistemi üzerinden verilen ödevler ile yürütülmeye çalışılmasının hem derslerin verimli geçmesinin önünde engel olduğuna hem de öğrencilerin içerisinde bulundukları imkansızlıklar içerisinde onları zorladığına değinilmiştir. Dolayısıyla, öğrencilerin lisans eğitiminde kazanmaları gereken yeterlikleri karşılamada sürecin yeterince verimli olmadığ 1 yorumu getirilmiştir. Örneğin, Ö10 kodlu öğrenci uzaktan eğitimin ödevden ibaret bir hale getirildiğini, Ö14 kodlu öğrenci ise yoğun ödevler sebebiyle öğrenmenin verimli bir şekilde gerçekleşemediğini savunmuştur.
Açıkçası bu dönemde ödev yapmaktan uyuyamaz olduk. "Uzaktan eğitim”den anlaşılan tek şeyin ödev yapmak olmadığını düşünüyorum. \#Ö10
Demek istediğim o ki, ben bu işin uzaktan eğitimle ve ödevlerle geçilen bir sinıfin bize hiçbir faydası yok. Yani sınıf geçiliyor lakin boş ve hiçbir şey ögrenilmeden geçiliyor. \#Ö14

\section{Karşıışıılan Engeller}

Katılımcılar, uzaktan eğitim sürecinde yaşadıkları başlıca engelleri araç gereç yetersizliği ve eğitim ve teknik destek yetersizliği olarak ifade etmişlerdir. Öğrencilerin birçoğu sürecin başlaması ile birlikte karar alıcıların öğrencilerin tümünün internet erişimine sahip olduğu ön kabulu ile süreci tasarladıklarını ve bu durumun kendileri için adaletsiz bir durum ortaya çıkardığını söylemişlerdir. İnternet sorunları özellikle senkron işlenen derslerde ve sınavlarda öğrencileri zor durumda bırakmıştır. Aşağıdaki örnekte öğrenci evinde internetin olmamasından dolayı özellikle senkron işlenen derslere katılım konusunda yaşadığı sorunu dile getirmiştir:

Teknoloji çağıında yaşasak da maalesef her öğrenci teknolojiye kolay ulaşamıyor. Benim evimde Wi-Fi bağlantısı yok. Bu yüzden senkron derslere girmem çok zor oluyor. \#Ö12

Aşağıdaki örnekte ise öğrenci yaşadığı coğrafi bölgeden kaynaklı yaşadığı internete erişim probleminden bahsetmiştir.

Derslere katılım konusunda çeşitli sorunlar, zorluklar yaşlyorum. Bunlar teknolojik zorluklar, psikolojik zorluklar vs. Şöyle ki genelde internetim kısitlı oluyor, kısitlı olmasa bile iyi çekmiyor; internetin çekmemesi dă̆ başında bir köyde yaşamamdan kaynakl 
galiba. Bilgisayarım yok, ki en azından çoğu hoca bilgisayar gerektiren ödev vermedi bir hocamız hariç. O ödevi gözden çıkardım. Internet iyi çekmediği için hazırladı̆̆ım bir ödevi DYSye veya classroom vb. Yüklerken biraz zaman kaybediyorum, hemen yüklenmiyor. \#Ö17

Katılımcıların birçoğu teknolojik yetersizliklerden kaynaklı yaşadıkları sorunları belirtmişlerdir. Örneğin, Ö11 kodlu öğrenci bu sürecin öngörülememesi sebebiyle birçok kaynaktan uzak kalmak durumunda kaldığını paylaşmıştır:

Şahsen bu sistemi düzenli olarak takip etmeye çalışlyorum fakat üç haftalık diye memleketime geldiğim bu salgında yanımda bilgisayarımı, dersler için gerekli olan materyalleri ve kitaplarımı yanımda getirmedim. \#Ö11

Katılımcılardan Ö34 ve Ö19 pandemi sürecinin başında bilgi sahibi olmadıklarından ötürü kaynaklarını yanında getirmediğini, bu sebeple de derslerin uzaktan devam etmesinin kendisi için erişilebilir kaynaklar açısından büyük sıkıntıya düşürdügünü belirtmiştir. Katılımcılar pandemi sürecini evde geçirirken yeterli imkanlara sahip olamadıklarını ve bu da pandemi sürecindeki derslerin verimli geçmesini engellediğini savunmuşlardır.

Bu süreçte ailemin yanına gelirken laptop ve kitaplarımı yanıma almadığım için ödevleri yaparken biraz zorlanıyorum açıkçası. Telefondan yeni programlar bulup daha iyi nasıl yapabilirim ve daha kolay hocalara nasıl ödevleri yollayabilirimin çabasını veriyorum. Evimde wifi olmadı̆̆ için kendi internetimle sınırlı araştırmalar yapabiliyorum. Ve bu yaptığım araştırmalar yanımda kitaplarım olmadı̆̆ için internet bilgileri ile sınırlı kalıyor. \#Ö34-Görüşme

Belki de çoğu kişi problemlerini hala çözemiyor ve teknoloji açısından zorluklar çekiyor. Bu zorlukların sadece teknolojik açıdan ibaret olduğunu düşünmüyorum. Biz memleketlerimize gelirken bu sürecin 3 haftalık bir süreç olduğunu düşünüyorduk ama neredeyse yaklaşık bir buçuk aydır buradayız. Çoğu kaynağımız yanımızda değil ve imkanlarımız kısitl. \#Ö19

Katılımcıların karşılaştıkları engellerden biri de evlerinde yeterince teknolojik imkanlar bulunmaması ve bu kısıtlı imkanları evdeki diğer aile üyeleri paylaşmak durumunda kalmaları olmuştur. Özellikle senkron işlenen derslere katılımın beklendiği durumlarda, öğrencilerin ikilemde kaldığ1 öğrenilmiştir. Örneğin, Ö5 ve Ö8 kodlu katılımcılar evdeki teknolojilerin paylaşılması gerektiği durumlarda yaşadıkları sorunları belirttikleri görülmüştür.

Evimizde 1 tane bilgisayar var ve 3 kardeşiz. Bilgisayar onlara da lazım olabiliyor. Ablam öğretmen olduğu için öğrencilerine online ders yapmak zorunda o gün o saatte eğer ablam öğrencilerine ders anlatmıyorsa derse katılabilirim. Bu yüzden bazı derslere katılamıyorum. \#Ö5

Çoğu hocamız her hafta olmak üzere ödev veriyor ve bu gerçekten yetişmiyor çünkü ödev yapmak öyle kısa sürmüyor. Bu sefer kardeşlerim zor durumda kaltyor bazen geceleri uyumayı ödevlerimi yapıyorum sabah onlar kullanabilsin diye bilgisayarl. Canlı ders için evdeki zaman, oda kisitlılı̆̆ bile oluyor. \#Ö8

Katılımcılar ayrıca evde geçirdikleri zamanın tamamen derslere ayrılabileceği kabulünün yanlış olduğunu ve evde olmaları sebebiyle farklı sorumluluklara sahip olduklarını belirtmişlerdir. Ders sorumlularının bu konuda tam anlamıla bir anlayış göstermemelerini eleştirmişlerdir. Öğrenciler, kardeşlere bakma, ev işleri, tarla işleri gibi birçok farklı örnekler sunarak evde geçirilen zamanda tam anlamıyla derslere odaklanamadıklarını belirtmişlerdir.

Geleneksel yöntemlerden biraz uzaklaşılmall. Bazen zamanında girmekte zorluk yaşayabiliyoruz çünkü evde olmamız bütün gün boş olduğumuz anlamına gelmiyor. Evde ailemize karşı sorumluluklarımız oluyor. \#Ö13 
Ö30 kodlu öğrenci ise pandemi sürecinde uzaktan eğitimin ödevler üzerinden yürütülmesini eleştirerek, bu durumun yaşadığı teknolojik imkansızlıklar ile birleşince salgında sağlığını tehlikeye atabilecek boyutlara ulaştığını paylaşmıştır.

Gerçekten bu kadar yoğunlukta ödev vermenin mantığını anlayamıyorum. İlk ay evimde internet yoktu ve birçok ödevimi yaparken komşularımdan yardım istediğim gündemde salgindan dolayı uzaktan ögretime geçtik ama biz hala insanlarla temasa geçmek durumunda kalyyoruz. \#Ö30

Öğrenciler kendilerinin sahip oldukları teknolojik bariyerlere ek olarak ders sorumlularının teknoloji ile ilgili karşılaştıkları sorunların öğretim süreçlerine nasıl etki ettiklerini paylaşmışlardır. Özellikle senkronize etkileşime dayanan süreçlerde ders sorumlularının karşılaştıkları sorunların başta zaman kaybı olmak üzere bir takım aksaklıklara sebep olduklarını belirtmişlerdir:

\title{
Teknoloji bilgisi az olan öğretmenler canlı ders sırasında bir sorun ile karşılaş̧tı̆̆ında
} çözmekte zorlanabiliyorlar ve zaman kaybl yaşanabilmektedir. \#Ö28

Katılımcılar son olarak öğretmen-öğrenci ilişkisi konusunda yaşadıkları sorunları ve özellikle iletişim konusunda yaşadıkları sorunları belirtmişlerdir. Pandemi süresince katılımcıların ders sorumluları ile iletişime geçememesi sebebiyle derslerle ilgili gerekli bilgilendirmeleri sağlıklı bir şekilde edinemediklerini ve bunun sonucunda süreci büyük bir sıkıntı içerisinde yaşadıklarını paylaşmışlardır. Ö24 kodlu öğrenci süreç içerisinde iletişim sorunu sebebiyle süreçte sıkıntılar yaşadığını belirtmiştir:

\begin{abstract}
Benim açımdan bu da çok iyi fakat o an aklıma takılan bir soruyu soramıyorum ve bu soruyu soracak bir hoca da daha sonrasinda zor bulunuyor. Bu nedenle bazl soru işaretlerimi gidermede sıkıntı yaşıyorum. Bazı konularda ayrıntılı bilgileri vermedikleri de oluyor, bu da olumsuzluklarindan biri. \#Ö24
\end{abstract}

\section{Öğrenme Ortamı}

Öğrenme ortamı teması altında, öğrenciler süreç içerisinde kullanılan farklı öğrenme ortamlarına yönelik düşünce ve deneyimlerini ortaya koymuşlardır. Öğrenciler, genel olarak öğrenme ortamı ne kadar kullanıcı dostu ise süreçte karşılaşılan sorunların da o derece az olduğunu belirtmişlerdir. $\mathrm{Bu}$ noktada öğrenciler, zoom ya da meet gibi farklı teknolojilerin kullanımına değinmişlerdir:

\section{Canlı dersler genel olarak "meet” uygulaması üzerinden yürütülüyor ve kullanımı çok kolay. Herhangi bir sıkıntı çekmedim. \#Ö9}

Bununla birlikte pandemi sürecinde uzaktan verilen eğitimde, öğrenme ortamlarının amacı doğrultusunda kullanılmadığ 1 , kullanmak için kullanıldığı ya da yeterince verimli bir süreç yürütülemediği gibi eleştirileri dile getirmişlerdir. Bu noktada öğrenme ortamının sunduğu fonksiyonların yeterince kullanamaması sebebiyle sürecin yeterince verimli gerçekleştirilemediği savunulmuştur.

Öğrenme ortamında sohbet açıp ders yapmak sadece klavye dersi oluyor. Çünkü hocalarımız konuşurken söyleyecekleri her şeyi yazma çabasında oluyorlar. \#Ö16

Bazı hocalar ise ders yönetim sistemi üzerinden konuşma yeri açıp oradan yazarak ders anlattyorlar ve bu zor oluyor. Yazll olarak zaten atılan slaytlarda zaten hepsi var ve ögrenciler bu yüzden oturup dinlemiyor. Uygulamayı açıp genelde bakmıyoruz bile. Sirf yoklama için orada açık tutuyoruz, o sırada başka ödevlerle ilgileniyoruz. "En azından başka uygulama üzerinden yapalım" gibi teklifleri kabul etmiyorlar ancak biz bundan verim alamiyoruz. \#Ö10

Ayrıca yapılan görüşmeler sonucunda farklı öğrenme ortamlarının karşılaştırılarak birbirlerine göre avantaj ve dezavantajlarından bahsedilmiştir. Öğrenciler genel olarak ders yönetim sistemini kullanışılı bulsalar da Google Classroom, Zoom ya da diğer ortamların da belirli avantajlara 
sahip olduklarını belirtmişlerdir. Bu noktada dersin içeriği ve işlenişi, dersin sorumlusunun yeterliklerinin ve son olarak öğrencilerin sahip oldukları teknolojik imkanlar göz önünde bulundurularak seçim yapılması gerektiğini belirtimişlerdir. Aşağıdaki örneklerde Ö18 ve Ö34 kodlu öğrenciler süreç içerisinde kullandıkları farklı teknolojileri kıyaslama yoluna gitmiştir:

Ben bizim DYS sistemini beğeniyorum hocalar geri dönütte verebiliyorlar. Google classroomu kullanan hocama DYSden ödevi attı̆̆mda bozuldu dysnin bu sistemini sevmiyorum. Google clasroomdan ödevi paylaştı̆̆ımızda aynen paylaştı̆̆ımız gibi gidiyor o yüzden Google classroom kullanılmasın beğeniyorum ZOOMu bu süreçte öğrenmiş olduk eylülde devam ederse daha iyi kullanabiliriz başka ögrenme ortamı kullanmadık. \#Ö18-Görüşme

Dys güncellemesiyle birlikte çok iyi oldu. Hocalarla iletişim kurabiliyoruz. Onun dışında zoom ve meet kullandım. meet çok kolaydı Türkçeydi. Hoca istediği gibi yönetebiliyordu. Ona alışınca zoomu kullanırken zorlandım açıkçası diğerlerini kullanmadığım için pek bir şey diyemiyorum.” \#Ö34-Görüşme

\section{Öneriler}

Katılımcılar pandemi sürecindeki çevrim içi öğrenme deneyimleri doğrultusunda, sürecin daha verimli yürütülebilmesine yönelik önerilerde de bulunmuşlardır. Bu kapsamda ders sorumlularının çevrim içi öğretim sürecini tasarlamadan önce öğrencilerden bilgi alarak bir nevi ihtiyaç analizi gerçekleştirmeleri önerilmiştir. Bu analiz sürecinde öğrencilerin istekleri, imkanları, yeterlikleri gibi faktörlerin göz önünde bulundurulmasının gerekliliği vurgulanmıştır.. Ö6 kodlu öğrenci sürecin başında öğrencilerin isteklerini dinlemenin öneminin altını çizmiştir:

Öğrencileri dinlerdim ne istediklerini ögrenip olur/olmaz/neden olmaz seçeneklerini tartışırdım. Daha sonra dersten en iyi verim almayı sağlayacak uygulanabilir yolları denerdim \#Ö6

Ayrıca farklı derslerde verilen ödevlerin bir birine benzemesinden kaynaklı öğrencilerin bu ödevlerin faydalı olmadığını ve bu yüzden kendilerini daha iyi geliştirebilecekleri ödevlerin verilmesi ve derslerin bu kapsamda yürütülmesinin uygun olacağı vurgulamışlardır.

\section{Ĕ̆er eğitim fakültesinde öğretim üyesiysem uygulamalar ile dersimi ilişkilendirip ödevler isterdim. Bu dersimle mümkün değilse bir ögretmenin okumuş olmasl gereken kaynakları okutmalarını isterdim. Çünkü zaten her ögretim üyesi hemen hemen aynı ödevleri veriyor. Makale oku slayt oku raporla gibi. \#Ö11}

Katılımcilar senkron derslerin verimliliğini israrla vurgularken derslerin öğrencileri de mağdur etmeyecek bir şekilde belirlenen zaman aralıklarında çevrim içi senkronize olarak işlenmesi gerektiğini belirtmişlerdir. Senkron derslerin gerek ders sorumlusu gerekse de öğrenciler için yorucu olduğunu kabul eden katılımcılar, ödev vermenin ya da kaynak paylaşımının anlık etkileşim kadar verimli olmadığını düşünmüşlerdir.

Hiçbir öğrencimi mă̆dur etmeyecek şekilde bir planlama hazırlardım. Internet sorunu eğer olmazsa bir uygulama belirleyip oradan derslerimi yürütürdüm. Google Classroom gibi \#Ö5

Ödevler devam etsin ama çok fazla ve yorucu ödev değil de bunun yanında canlı yayınların olmasını tercih ederim. Canlı dersler beni motive ediyordu. \#Ö18-Görüşme

Dersleri uzaktan eğitim sürecinde yapılabilecek şekilde ayarlardım aralıklı şekilde bir ortam hazırlardım zoom gibi zoomda olabilir bu saatlerde derse girmek zorundayız sonuçta okulda olduğumuzda da derse katılmak zorundaydık. Bu tarz programlarla bence yüz yüze eğitim yapllabilir uzaktan görüntülü olarak. \#Ö35-Görüşme

Katılımcıların lisans eğitimlerinin uygulamalı eğitimin ağırlıklı olduğu dönemde olmaları sebebiyle uygulama derslerine ayrı bir parantez açmışlardır. Dolayısıyla, öğretmenlik uygulaması 
gibi derslerin uygulama boyutu da göz önünde bulundurulması suretiyle öğrencilerin deneyim kazanabilmelerinin yolunun açılmasının gerektiği paylaşılmıştır. Katılımcılar ayrıca uygulamalı derslerin ödev ya da sunu yoluyla gerçekleştirilmesini eleştirirken bu şekilde dersin amaçlarına ulaşmasının mümkün olmadığını savunmuşlardır. Aşağıda yer alan alıntıda Ö19 kodlu katılımcı pandemi sürecinde gerçekleştirdiği öğretim deneyimini uygulamalı derslerde kullanabileceğini belirterek bu şekilde devam edilen bir sürecin uygulamalı derslerin doğasına daha uygun olacağını söylemiştir:

\begin{abstract}
4. Sinif derslerim uygulamaya yönelik bu yüzden mesela uygulama derslerinde herhangi sinif ortamina katılmak isterdim. Canll yayinla dersleri dinlemek isterdim. Bu yüzden belki bizim okulun okullarla anlaşması ve canlı olarak bizi katabilmesini isterdim. Diğer dersler slaytlar üzerinden olabilir. Illkokula giden kuzenlere yardım ettim. Bana verilen bir ödevin onlara yardım etmek olmasinı isterdim. Slaytlardan ve ödevlerden çok bunları tercih ederdim. \#Ö19-Görüşme
\end{abstract}

\title{
Sonuç ve Tartışma
}

Covid-19 pandemisiyle gelen uzaktan eğitim sürecinde sınıf öğretmenliği lisans öğrencilerinin çevrim içi öğrenme süreçlerindeki deneyimleri ve edinimleri bu çalışma kapsamında incelenmiştir. Ayrıca, sınıf öğretmenliği lisans öğrencilerinin gözünden pandemi sürecinde gerçekleşen uzaktan eğitim uygulamalarına ilişkin değerlendirmeleri ortaya konulmuştur. Çalışma kapsamında katılımcılar senkron ve asenkron derslerin dezavantajları ve avantajlarından bahsederek çoğunlukla senkron derslerin daha verimli geçtiğini belirtmişlerdir. Alanyazında uzaktan eğitim sürecindeki senkron ve asenkron derslerin avantaj ve dezavantajları ortaya konulmuştur. Örneğin Çakmak (2013) uzaktan eğitim sürecinde derslerin bir bölümünü yüz yüze eğitimle gerçekleştirilmesini ve asenkron derslerin genellikle kavram öğretimi gibi durumlarda kullanılmasını önermektedir. Hrastinski (2008) ise öğrencilerin çevrim içi eğitim sürecinde yaşadıkları psikolojik etkileri ortaya koyarken, senkron derslerde öğrencilerin akranlarıyla sürekli etkileşimde bulunmalarının motivasyonlarını arttırdığını ve senkron derslerin öğrenme deneyimine daha sosyal bir yön sağladığını belirtmiştir. Lammintakanen ve Rissanen (2005) senkron derslerin, başarılı bir öğrenme deneyimi için önemli olduğunu belirtmiştir. Araştırmadan elde edilen senkron ve asenkron derslerle ilgili sonuçlar, alanyazınla tutarlılık göstermektedir.

Araştırmadan elde edilen bir diğer sonuca göre öğrenciler yaşadığ 1 şartlardan dolayı teknolojik olarak yoksunluk çekmektedir. Yapılan görüşmelerde öğrenciler köylerde yaşadıkları için internete bağlanma sıkıntısı çektiklerini ya da internete hiç erişimleri olmadığını belirtmişlerdir. Lau ve diğerleri (2020) çalışmalarında Çin'de kırsal alanlarda yaşayan öğrencilerin uzaktan eğitime katılabilmeleri için yeterli donanıma ya da bağlantıya sahip olmadıklarını belirtmişlerdir. Pandemi döneminde Türkiye'de verilen uzaktan eğitimi değerlendirmeye ilişkin yapılan bir çalışmada, 17.939 öğrenci çalışmaya katılmış ve öğrencilerin \%63'ü uzaktan eğitime erişmek için evinde internet olmadığını, \%23'ü de uzaktan eğitime devam edemediklerini belirtmişlerdir (Karadağ ve Yücel, 2020). Ayrıca Türkiye'de YÖK (2020) 123 üniversitenin uzaktan eğitime hazır olduğunu belirtmiştir. Geriye kalan 85 üniversitenin binlerce öğrencisinin yine teknolojik yetersizliklerden dolayı eğitim göremediği söylenebilir.

Araştırmada, öğrencilerin uzaktan eğitimde karşılaştıkları bir diğer sorun öğretim elemanlarının uzaktan eğitim kapsamında yeterli dijital yetkinliğe sahip olmadıkları sonucudur. Öğretim elemanları teknolojik olarak yaşadıkları sorunlardan dolayı derslerde aksaklıklar yaşadıkları ve bunları çözme sürecinde dersin akışının bozulduğu yapılan görüşmelerde belirtilmiştir. Karadağ ve Yücel (2020) özellikle sosyal bilimler alanında görev yapan öğretim elemanlarının çoğunluğunun teknoloji kullanma yeterliliklerinin düşük olduğunu belirtmişlerdir. Benzer şekilde Üstün (2011) öğretim elemanlarının güncel teknoloji kullanım düzeylerinin yeterli olmaması, yeni teknolojiler konusunda ve harmanlanmış eğitim ortamlarına karşı bilgilerinin eksik olması, uzaktan eğitime karşı 
önyargılı olmaları ve bu tür eğitim süreçlerinin kendilerine yük teşkil etmesinden kaynaklı uzaktan eğitimin yeterli düzeyde uygulanmadığını belirtmiştir.

Araştırmada öne çıkan bir diğer sonuç ise öğrencilerin uzaktan eğitimde öğrenme ortamları hakkındaki görüşleridir. Yapılan görüşmelerde öğrencilerin özellikle dersin öğretim üyesi ile kamera ve mikrofon ile birlikte iletişim kurabildikleri dersleri tercih ettikleri sonucuna ulaşılmıştır. Öğrenciler, öğretim elemanlarının ödev yoluyla ya da yazarak iletişim kurdukları derslerin kendilerine fayda sağlamadığını belirtmişlerdir. Uzaktan eğitimde kullanılan öğrenme ortamlarının ve derste kullanılan materyallerin zenginliğinin ve kalitesinin verilen eğitimin niteliğini önemli bir şekilde etkilediği belirtilmiştir (Chao ve diğerleri, 2006). Elde edilen bu sonuçlardan öğretim üyelerinin ödevle ya da sohbet penceresi üzerinden yaptıkları derslerin sadece günü kurtarmak olduğu düşünülmektedir. Uzaktan eğitim izole edilmiş, bağımsız bir faaliyet olarak görülmemeli, öğrencilerin ve öğretim elemanlarının öğrenmede ortak oldukları bir etkinlik olmalıdır (Young, 2006). Öğretim elemanlarının görevlerini bu kadar basit yollarla gerçekleştirmeleri eğitim açısından olumsuz bir tablo olarak ortaya çıkmıştır.

\section{Çevrim İçi Eğitim için Öneriler}

Araştırma sonuçlarına göre çevrim içi eğitimin nitelikli olması için bazı öneriler sunulmuştur. Öğrencilerin ders programını sürekli takip etmesi ve düzenli çalışması her türlü eğitim ortamında önemli olduğu gibi çevrim içi eğitimde de önem taşımaktadır. Bir diğer önemli unsur da öğrencilerin senkron ve asenkron derslere düzenli katılım sağlamasıdır. Öğretim elemanlarının derslerini planlarken öğrencilerin katılımını sağlamaya yönelik daha etkileşimli ve işbirlikli çalışmalara uygun içerikler geliştirmeleri önerilmektedir. Dolatısıyla öğrencilerin sınıf arkadaşlarıyla uzaktan işbirliği içinde çalışmaları ve ders sorumlusuyla sürekli etkileşim içinde bulunmaları çevrim içi eğitim sürecini daha da nitelikli hale getirecektir. Bu süreçte yer alan paydaşların uzaktan eğitim sürecine yönelik yeterliklerini ve motivasyonlarını arttırmaya yönelik adımların atılması önerilmektedir. Öğretim elemanlarının yakın gelecekte eğitimde daha fazla yer alacağı belli olan teknoloji kullanımına açık olmaları ve teknolojik gelişmeleri takip etmeleri önerilmektedir. Öğretim üyelerinin çevrim içi derslerini süreç başlamadan önce planlamaları ve süreç içerisinde öğrencilerden aldıkları dönütler doğrultusunda düzenlemeler gerçekleştirmeye açık olmaları önerilmektedir. Bu şekilde öğrencilerin daha çok derslere katılması sağlanabilir. Bununla birlikte çevrim içi eğitimin niteliğini artıracak diğer bir uygulama olarak senkron ve asenkron derslerin harmanlanarak verilmesi önerilmektedir. Çalışma sonucunda ortaya çıkan öğrencilerin yaşadığı teknoloji yoksunluğu ve bunun uzaktan eğitim öğretim sürecinde doğurduğu olumsuz sonuçlar göz önünde bulundurularak öğrencelere daha iyi teknolojik imkanlar sunulmasına destek olunması ve pandemi sürecinde uzaktan eğitim-öğretim süreçlerinin bir zorunluluk haline gelmesi dolayısıyla sürecin daha erişilebilir teknolojik araç gereçlerle yürütülmesi önerilmektedir.

\section{Kaynakça}

Arkorful, V. ve Abaidoo, N. (2015). The role of e-learning, advantages, and disadvantages of its adoption in higher education. International Journal of Instructional Technology and Distance Learning, 12(1), 29-42.

Bilgiç-Doğan, G. H. (2014, Aralık 31). Eğitimde Teknoloji. Eğitimde Teknoloji Web sitesi: http://www.egitimdeteknoloji.com/uzaktan-egitim-yasam-boyu-ogrenme-nedir/

Chao, T, Saj, T. ve Tessier, F. (2006). Establishing a quality review for online courses. Educause Quarterly, 3, 32-39. 
Ertmer, P.A. (1999). Addressing first- and second-order barriers to change: Strategies for technology integration. Educational Technology Research \& Development (ETR \& D), 47, 47-61. https://doi.org/10.1007/BF02299597

Kaya, Z. ve Önder, H. (2002). İnternet yoluyla öğretimde ergonomi. The Turkish Online Journal of Educational Technology (TOJET), 1(1), 48-54.

Koehler, M. ve Mishra, P. (2008). Introducing TPCK. In AACTE Committee on Innovation and Technology (Eds.), The handbook of technological pedagogical content knowledge for teaching and teacher educators (pp. 3-29). Lawrence Erlbaum Associates Publishers.

Karadağ, E. ve Yücel, C. (2020). Yeni Tip Koronavirüs Pandemisi Döneminde Üniversitelerde Uzaktan Eğitim: Lisans Öğrencileri Kapsamında Bir Değerlendirme Çalışması. Yükseköğretim Dergisi, 1-12. https://doi.org/10.2399/yod.20.730688

Lammintakanen, J. ve Rissanen, S. (2005). Online learning experiences of university students. In C. Howard, J. Boettcher, L. Justice, K. Schenk, P.L. Rogers, ve G.A. Berg (Eds.), Encyclopedia of distance education (Vol. 3, pp. 1370-1374). Idea Group Reference https://doi.org/10.4018/978-1-59140-555-9.ch206

Lau, J., Yang, B. ve Dasgupta, R. (2020). Will the coronavirus make online education go viral? timeshighereducation. com: https://www.timeshighereducation.com/features/ willcoronavirus-make-online-education-go-viral

McMillan, J.H. (2004). Educational Research: Fundamentals for the Consumer. (4th ed.). Pearson Education, Inc.

Young, S. (2006). Student views of effective online teaching in higher education. The American Journal of Distance Education, 20(2), 65-77. https://doi.org/10.1207/s15389286ajde2002_2

UNDP. (2020, Mart 23). United Nations Development Programme. UNDP Web Sitesi: https://www.tr.undp.org/content/turkey/tr/home/presscenter/articles/2020/03/COVID-19dayanisma.html. https://doi.org/10.15511/tahd.20.00256

Yıldırım, A. ve Şimşek, H. (2008). Sosyal Bilimlerde Nitel Araştırma Yöntemleri (9. Baskı). Seçkin Yayıncilik.

YÖK. (2020, Mayıs 3). Yükseköğretim Kurumu. Yükseköğretim Kurumu Web sitesi: https://www.yok.gov.tr/Sayfalar/Haberler/2020/uzaktan-egitime-yonelik-degerlendirme.aspx

Zhang, D. ve Nunamaker, J. F. (2003). Powering e-learning in the millennium: An overview of elearning and enabling technology. Information Systems Frontiers, 5 (2), 207 - 218. 